\title{
NOTES
}

\section{SPECIMEN DAYS: THE THERAPEUTICS OF SUN-BATHING}

For "the past two summers," Whitman wrote in 1877, Nature-"the invisible physician" - "has been strengthening and nourishing my sick body and soul as never before." The 27 August 1877 entry in Specimen Days, captioned "A Sun-BathNakedness," vividly recounts how Whitman communes with nature, absorbing the healing virtues of fresh air, mud, and water at his secluded brookside retreat on the Stafford farm at Timber Creek, New Jersey, and tells how "the sure virtues of creekshore, and wood and field ... begin to make a new man of me. Every day seclusionevery day at least two or three hours of freedom, bathing, no talk, no bonds, no dress, no books, no manners." Hobbling into the "dell," formerly a marl pit but now overgrown with foliage, through which a small stream runs, and unclothed except for a hat and "easy shoes," he takes his "Adamic air-bath and flesh-brushing from head to foot." The routine involves brushing "with the stiff-elastic bristles rasping arms, breast, sides, till they turn'd scarlet," then "partially bathing" in the brook, treating his feet to an "unctuous mud-bath," "rinsing in the crystal running watersrubbing with the fragrant towel," then walking about, "more of the bristle brush," and much idling and observing. In making a pitch for the boon of nudity - "the free exhilarating extasy of nakedness in Nature," he exclaims: "Sweet, sane, still Nakedness in Nature! - ah if poor, sick, prurient humanity in cities might really know you once more!" For only in this union with nature, the poet claims, can health be found; only thus has he obtained physical and spiritual healing. ${ }^{1}$

The charm and intimacy of Whitman's prose may persuade us that this sunbathing regimen was his own romantic brain child, but it was in fact a variant of the therapeutic air cures and camp cures prescribed by his distinguished physician Dr. S. Weir Mitchell and by other doctors in the 1870 s and 1880 s. Some particularly intriguing sidelights on Whitman's self-ministrations are afforded in Dr. Russell Thacher Trall's The Hygienic Hand-Book: Intended as a Practical Guide to the SickRoom (New York: Samuel R. Wells, 1872). Whether Whitman knew the Hygienic Hand-Book is uncertain, but there can be no doubt that he was familiar with Dr. Trall's ideas. Most of the twenty or so nontechnical medical books by this hydropathic physician - all of them characterized by common sense-were published by Fowler and Wells, the covert publishers of the second (1856) edition of Leaves of Grass. During Trall's tenure as assistant editor of Fowler and Wells' weekly newspaper Life Illustrated Whitman became what Madeleine B. Stern calls "a regular staff writer" on that journal. Whitman's impressionistic sketches, written between November 1855 and August 1856, appeared during Trall's editorship. ${ }^{2}$ Dr. Trall was also the proprietor of the Hygieo-Therapeutic Institute, in Manhattan, a hydropathic medical college at whose anatomical museum Whitman could have found inspiration for the catalogue of bodily attributes that constitutes the concluding (ninth) section of "I Sing the Body Electric," first added to that 1855 poem in the 1856 edition. ${ }^{3}$

The regimen that Whitman so eloquently describes in Specimen Days conforms in many details to what Dr. Trall defines as an air-bath: 
AIR-BATH. The whole body is suddenly exposed to cool or cold air, or even to a strong current, and an excellent and invigorating process it is in many cases. There is no danger from it provided the surface has a comfortable glow or temperature at the time, and the circulation is maintained by active exercise. Friction with the hand, a sheet-towel, or fleshbrush, is beneficial at the same time. (Hand-Book, p. xi.)

Nor did the hydropathist neglect water therapy, recommending, in this book for invalids, baths in a copper-lined tub, filled with warm water while a slight current of "galvanism" is induced through the water (p. xiii). (In Trall's Hydropathic Encyclopedia, 1853, which Whitman apparently knew, and in his Family Gymnasium, 1857, which he reviewed in the Brooklyn Daily Times, Trall had prescribed every known sort of water treatment.) ${ }^{4}$ Whitman, whose doctors often treated his paralysis by inducing electrical currents, would also have known that a flesh brush was supposed to generate a mild electrical current.

Concerned, like Whitman, with the deleterious effects on city dwellers of living in airless cellars and dark tenements and breathing the "scrofulous humors" conducive to consumption, Dr. Trall called attention

to the relation between sunshine and vitality. Invalids should seek the sunlight as do the flowers-care being taken to protect the head when the heat is excessive. Exposing the whole skin in a state of nudity, frequently, to the air, and even to the rays of the sun, is a very invigorating practice. For scrofulous persons this is particularly serviceable. (p. xxx.) ${ }^{5}$

Here, then, was a medical prescription for nudity. Prior to the isolation of the tuberculosis bacillus in the 1880 s, moreover, the scrofula referred to by Dr. Trall was generally confused with tuberculosis; and in fact Whitman's body bore evidence of the ravages of tuberculosis.

Since his stroke in January 1873 Whitman had been hemiplegic-paralyzed on the left side of the body. Dr. Trall's comments on hemiplegia also help us to see some relationship between Whitman's paralysis and his attempts to regain a measure of health. "Hemiplegia is more particularly connected with or caused by torpidity of the liver," declared Trall; it is aggravated by bad bowels, "hence persons of sedentary habits, gluttons, and those who are subject to great mental excitements, while their diet is particularly constipating, are commonly the subjects of this form of palsy" (pp. 211-212). In an era in which most bodily malfunctions were traced to the alimentary tract, this observation was similar to the diagnoses of Whitman's own physicians. Drs. William Beverly Drinkard and Matthew Grier, who had attended the poet, both called attention to Whitman's digestive disorders and his emotional agitation; and it is fair to say that Whitman became obsessed with his own digestive functions. To treat hemiplegia Dr. Trall prescribed a temperate diet, fresh air, massage, baths, and abstinence from medication. By 1877 Whitman had come to detest all medicines and was enthusiastic about fresh air and massage.

We may safely conclude that the regimen of temperance, fresh air, water, massage, nakedness, and good cheer which helped the poet to achieve periods of respite from the rigors of paralysis and which Specimen Days elevates to a metaphysical experience was grounded in the concept of the air cure and was a variant of conventional and hydropathic medical practice. 


\section{NOTES}

1 Specimen Days, in Prose Works 1892, ed. Floyd Stovall (New York: New York University Press, 1963), 1:150-152.

2 Madeleine B. Stern, Heads $\mathcal{E}$ Headlines: The Phrenological Fowlers (Norman: University of Oklahoma Press, 1971), pp. 115-117. The Life Illustrated sketches are collected in New York Dissected, ed. Emory Holloway and Ralph Adimari (New York: Rufus Rockwell Wilson, 1936).

3 Thoreau and Alcott stayed at the Institute when they came to visit Whitman in the autumn of 1856. Alcott, who lectured there, praised its display of "the best models of the Human Body, exhibiting its organs and functions in health, also diseased." See The Letters of Bronson Alcott, ed. Richard L. Herrnstedt (Ames: Iowa State University Press, 1963), p. 207 and pp. 200-207, passim; The Fournals of Bronson Alcott, ed. Odell Shepard (Boston: Little, Brown and Co., 1938), pp. 286-291.

4 Harold Aspiz, Walt Whitman and the Body Beautiful (Urbana and London: University of Illinois Press, 1980), pp. 44-45, 257.

5 Trall decried tenement dwellings and made a plea for fresh air in his Sexual Physiology (New York: Wood and Holbrook, 1871), p. 252. In 1877 Whitman remarked on the irony that Americans "leading a free natural open-air life should, directly they make a little money, want to go in for sofas, expensively furnished rooms, dress, and such like; yet it seems to be a kind of law, a kind of necessity that they should do so." See Edward Carpenter, Days with Walt Whitman (New York: Macmillan, 1896), p. 23.

\section{WHITMAN'S DARK SEA: A NOTE ON "PATROLING BARNEGAT"}

Although nineteen years of life remained to Walt Whitman after his paralytic stroke in 1873, his poetic output was significantly diminished during those years; and of the poems he wrote, only a few stand out as being of consequence, equal to all but the very best of his earlier achievements. Perhaps the last of these notable poems is "Patroling Barnegat," published in 1880. It is a remarkable work that deserves to be better known.

"Patroling Barnegat" describes a fierce winter storm as viewed from the shores of Barnegat Bay, New Jersey; the time is around midnight, and in the darkness a few people stand in a group, looking out at the turbulent sea. Whitman may actually have seen the storm he describes, but that is unlikely; in 1880 he was in no condition to be standing out on the beach in violent winter weather, at nighttime, and there is no indication in his writings that he did any such thing. It is more probable that the poem finds its origins in an earlier storm mentioned in the Specimen Days entry for 4 June 1880 . In this passage Whitman recalls a few moments among his "rare and blessed bits of hours, reminiscent, past - the wild sea storm I once saw one winter day, off Fire Island. . . ." It is unlikely that in June of 1880, when "Patroling Barnegat" was published, Whitman would be remembering so vividly a storm off Fire Island had he more recently witnessed one so impressive as that in his poem. The reason for moving the location to Barnegat Bay would be to increase the sense 